\title{
Treatment of allergic rhinitis and urticaria: a review of the newest antihistamine drug bilastine
}

\author{
This article was published in the following Dove Press journal: \\ Therapeutics and Clinical Risk Management \\ 13 April 2016 \\ Number of times this article has been viewed
}

\author{
Xue Yan Wang' \\ Margaret Lim-Jurado² \\ Narayanan Prepageran ${ }^{3}$ \\ Pongsakorn Tantilipikorn ${ }^{4}$ \\ De Yun Wang ${ }^{5}$ \\ 'Department of Allergy, Beijing \\ Shijitan Hospital, Capital Medical \\ University, Beijing, People's Republic \\ of China; ${ }^{2}$ St Luke's Medical Center, \\ Quezon City, Manila, Philippines; \\ ${ }^{3}$ Department of Otorhinolaryngology, \\ Head \& Neck Surgery, University \\ Malaya Faculty of Medicine, Kuala \\ Lumpur, Malaysia; ${ }^{4}$ Rhinology and \\ Allergy Division, Department of \\ Otorhinolaryngology, Faculty of \\ Medicine Siriraj Hospital, Mahidol \\ University, Bangkok, Thailand; \\ ${ }^{5}$ Department of Otolaryngology, Yong \\ Loo Lin School of Medicine, National \\ University of Singapore, Singapore
}

Correspondence: De Yun Wang Department of Otolaryngology, Yong Loo Lin School of Medicine, National University of Singapore, IE Kent Ridge Road, Singapore II 19228

Tel +65 67725373

Fax +65 67753820

Email entwdy@nus.edu.sg

\begin{abstract}
Allergic rhinitis and urticaria are common allergic diseases that may have a major negative impact on patients' quality of life. Bilastine, a novel new-generation antihistamine that is highly selective for the $\mathrm{H}_{1}$ histamine receptor, has a rapid onset and prolonged duration of action. This agent does not interact with the cytochrome P450 system and does not undergo significant metabolism in humans, suggesting that it has very low potential for drug-drug interactions, and does not require dose adjustment in renal impairment. As bilastine is not metabolized and is excreted largely unchanged, hepatic impairment is not expected to increase systemic exposure above the drug's safety margin. Bilastine has demonstrated similar efficacy to cetirizine and desloratadine in patients with seasonal allergic rhinitis and, in a Vienna Chamber study, a potentially longer duration of action than fexofenadine in patients with asymptomatic seasonal allergic rhinitis. It has also shown significant efficacy (similar to that of cetirizine) and safety in the long-term treatment of perennial allergic rhinitis. Bilastine showed similar efficacy to levocetirizine in patients with chronic spontaneous urticaria and can be safely used at doses of up to fourfold higher than standard dosage ( $80 \mathrm{mg}$ once daily). The fourfold higher than standard dose is specified as an acceptable second-line treatment option for urticaria in international guidelines. Bilastine is generally well tolerated, both at standard and at supratherapeutic doses, appears to have less sedative potential than other second-generation antihistamines, and has no cardiotoxicity. Based on its pharmacokinetic properties, efficacy, and tolerability profile, bilastine will be valuable in the management of allergic rhinitis and urticaria.
\end{abstract}

Keywords: bilastine, second-generation antihistamines, allergic rhinitis, urticaria

\section{Introduction}

The frequency and impact of allergic diseases are often underestimated. ${ }^{1}$ A key facilitator of the allergic response is immunoglobulin $\mathrm{E}(\mathrm{IgE})$ that is present on the surface of mast cells and basophils. ${ }^{2}$ Interaction of the allergen with IgE and its receptor complex leads to activation of these cells and release of the substances, including histamine, that cause allergic symptoms. ${ }^{2}$

Because of the central role of histamine in allergic responses, many allergic conditions are treated with antihistamines, including allergic rhinitis and urticaria..$^{3,4}$ Antihistamines have been in clinical use for $>70$ years, and the pharmacological characteristics of these agents have been evolving over that time. ${ }^{5}$

The objective of this article is to review the current burden of allergic rhinitis and urticaria in Asia Pacific, to briefly describe the evolution of antihistamine pharmacology, and to systematically review the pharmacological characteristics and clinical results of bilastine, a new antihistamine that is highly selective for the $\mathrm{H}_{1}$ histamine receptor. 


\section{Research methodology}

For the systematic review of bilastine data, a PubMed search was undertaken of all publications including "bilastine" in the title and/or abstract. No date limits were applied. All preclinical and clinical trials were assessed for inclusion in the review. Attention was preferentially given to randomized controlled trials, with appropriate controls for variation and bias (eg, placebo group, blinding).

\section{Burden of allergic diseases in Asia Pacific \\ Allergic rhinitis}

Allergic rhinitis is a symptomatic condition of the nose caused by allergen exposure and IgE-mediated inflammation. ${ }^{6}$ Allergic rhinitis is defined as intermittent or persistent, and its severity is classed as mild or moderate-to-severe. ${ }^{6}$ Historically, symptoms of the condition were categorized as occupational, seasonal, or perennial, but this classification is now unsatisfactory because these categories are not necessarily mutually exclusive. ${ }^{7}$ In 2001, the document "Allergic rhinitis and its impact on asthma" (ARIA) recommended replacing the terms "seasonal" and "perennial" rhinitis by intermittent allergic rhinitis and persistent allergic rhinitis, respectively. ${ }^{8}$ Subsequently, "intermittent" and "persistent" are not precisely synonymous with seasonal and perennial allergic rhinitis.

Allergic rhinitis is frequently encountered in primary care. Patients report that allergic rhinitis has a marked detrimental effect on their sleep, social life, quality of life, and attendance and functioning at school and work. ${ }^{6,9-11}$ Another issue is that allergic rhinitis commonly coexists with other forms or allergic disease. Considerable clinical and epidemiological evidence also exists of an association between asthma and allergic rhinitis. ${ }^{12}$ It has been estimated that up to $75 \%$ of patients with asthma have rhinitis ${ }^{9,10}$ and that approximately one-third of patients with allergic rhinitis have asthma. ${ }^{10}$ Comorbid links between allergic rhinitis and sinusitis, conjunctivitis, otitis media, and nasal polyposis have been documented, although the extent of such links remains unclear. ${ }^{12}$ The economic burden of allergic rhinitis is frequently underrated, and indirect costs of the disorder are extensive. ${ }^{6,13}$

Allergic rhinitis is a worldwide health problem, with a prevalence estimated at between $10 \%$ and $30 \%$, and it is associated with considerable morbidity. ${ }^{11}$ The disorder is estimated to affect the lives of $>500$ million people worldwide. ${ }^{6}$ The burden is particularly high and increasing in Asia Pacific, where many people now live in crowded cities with high levels of environmental pollution. ${ }^{14}$ The Allergies in Asia Pacific survey reported an adult prevalence of $9 \%$ across the region, with $63 \%$ of patients having seasonal or intermittent allergies. ${ }^{11}$ However, the prevalence of allergic rhinitis subtypes does differ between countries in Asia Pacific. In several Southeast Asian surveys, 70\% of patients with allergic rhinitis had persistent disease and $\sim 30 \%$ had intermittent symptoms, ${ }^{15,16}$ whereas in the People's Republic of China, $25 \%$ of patients with allergic rhinitis had the persistent form and $75 \%$ had intermittent disease. ${ }^{17}$

\section{Urticaria}

Another common disease is urticaria. Patients with urticaria typically develop wheals (hives), angioedema, or both. ${ }^{4,18}$ Usually, about half of all patients with urticaria have associated angioedema. ${ }^{19}$ If the condition has a duration of $<6$ weeks, it is acute. If it persists for $>6$ weeks, or recurs, it is chronic. Symptoms of the disorder may endure for several months or years. ${ }^{20}$ The most frequent causes of acute urticaria, which may affect up to $15 \%-25 \%$ of all individuals at some stage in their lives, are viral infections (especially affecting the upper respiratory tract), food allergies, and drug adverse reactions. ${ }^{18}$ Physical effects, systemic disease, or long-term infection may also lead to urticaria/angioedema. ${ }^{20,21}$ In patients with chronic urticaria, the condition is often idiopathic (ie, has no discernible cause in $~ 55 \%-80 \%$ of cases); this is known as chronic spontaneous urticaria. ${ }^{19,22}$ The counterpart is chronic inducible urticaria, which is caused by physical stimuli such as cold, heat, sun, or pressure. ${ }^{4}$

Unfortunately, there are limited data on the burden of urticaria in Asia Pacific. Internationally, chronic spontaneous urticaria is estimated to have a point prevalence of $\sim 0.5 \%-1.0 \%$. ${ }^{1,23,24}$ The peak age of occurrence is usually between 20 years and 40 years, and typical disease duration is $1-5$ years, although this can be greater in many cases. As with allergic rhinitis, chronic urticaria is a devastating disorder that can have a major negative influence on a patient's quality of life, including vitality, sleep, mobility, and social life. ${ }^{23,25-27}$ Because of emotional distress, patients with chronic spontaneous urticaria often have anxiety, depression, and somatoform disorders. ${ }^{28}$ As a result, the societal burden of the condition is great in terms of both direct and indirect health care costs. ${ }^{23,26}$ The disorder is often managed improperly, for example, with the repetitive use of oral corticosteroids that have significant safety concerns. $^{29}$ 


\section{Role of histamine and the $\mathbf{H}_{1}$ receptor subtype in IgE-mediated allergic diseases}

Histamine has a key role in the pathophysiology of allergic inflammation. ${ }^{30}$ After exposure to an allergen, specific antibodies of the IgE type are produced in genetically predisposed individuals. ${ }^{30}$ These interact with receptors on the surface of basophils and mast cells. The consequence is a series of intracellular reactions culminating in exocytosis and the release of histamine and other inflammatory mediators such as platelet-activating factor and cytokines. ${ }^{4,30}$ Various drugs (eg, morphine) can also cause direct displacement of histamine from its storage granules. ${ }^{30}$

The consequences of histamine release include receptormediated smooth muscle cell contraction in the gastrointestinal and respiratory tracts, sensory nerve stimulation, vasodilation, plasma extravasation, and cellular recruitment, for example, to urticarial lesions. ${ }^{4,30}$ These effects lead to, among other things, erythema, flushing, nasal congestion, and pruritus. ${ }^{30}$

Besides its mediatory activity in the early allergic response, histamine contributes to the late allergic response by stimulating the production of cellular adhesion molecules, class II antigens, and cytokines. ${ }^{30}$
Four principal histamine receptor subtypes exist: $\mathrm{H}_{1}$, $\mathrm{H}_{2}, \mathrm{H}_{3}$, and $\mathrm{H}_{4}$. These are G-protein-coupled receptors that transfer extracellular signals via $G$ proteins, which act as intermediaries between cell surface receptors and intracellular second messengers (Figure 1). ${ }^{5,30} \mathrm{H}_{1}$ and $\mathrm{H}_{2}$ receptors are widely distributed throughout the body, but the $\mathrm{H}_{3}$ subtype is mainly located in the central nervous system (CNS) and the $\mathrm{H}_{4}$ subtype in hematopoietic tissues. ${ }^{30}$ The allergic response is primarily mediated by the $\mathrm{H}_{1}$ receptor subtype.

$\mathrm{H}_{1}$ receptors are ubiquitous and are found in the adrenal medulla, CNS, endothelial and epithelial cells, heart, immune cells, sensory nerves, and smooth muscle. ${ }^{30}$ In the CNS, most of the postsynaptic actions of histamine are mediated by $\mathrm{H}_{1}$ receptors. ${ }^{30}$ This leads to activity on sleep-wake cycles and probably explains the sedative effects noted with first-generation antihistamines that cross the blood-brain barrier. ${ }^{21}$ Via $\mathrm{H}_{1}$ receptors, histamine also causes smooth muscle cell contraction in the gastrointestinal and respiratory tracts and stimulation of sensory nerves. Outcomes include pruritus, sneezing, increased vascular permeability, and edema. ${ }^{30}$

Antihistamines are not structurally related to histamine and are not competitive antagonists of histamine binding

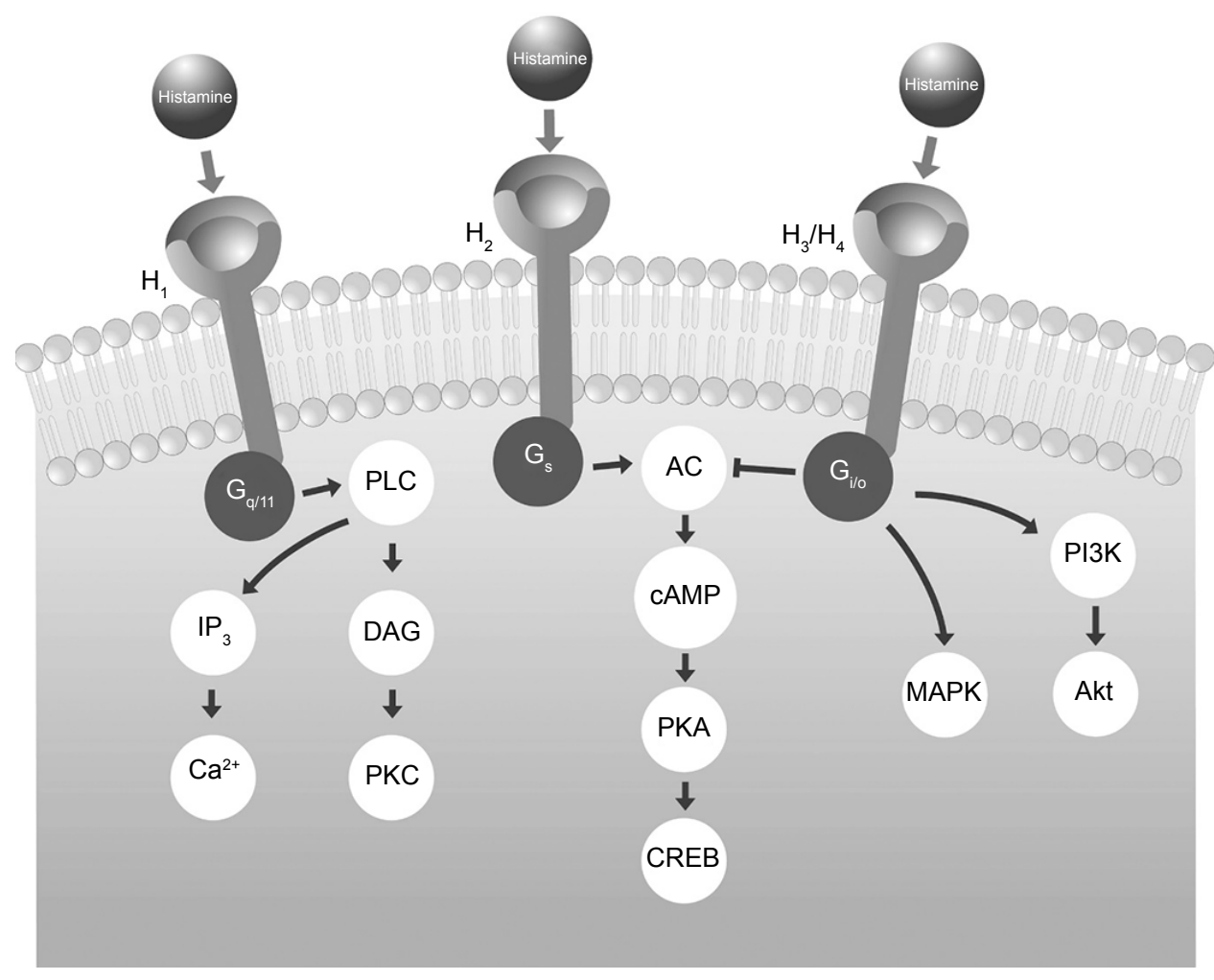

Figure I Intracellular signaling processes mediated by G-proteins after interaction of histamine with each receptor subtype.

Abbreviations: AC, adenylate cyclase; Akt, protein kinase B; cAMP, cyclic adenosine monophosphate; CREB, cAMP response element-binding protein; DAG, diacyl glycerol; $I_{3}$, inositol triphosphate; MAPK, mitogen-activated protein kinase; PI3K, phosphoinositide 3-kinase; PKA, protein kinase A; PKC, protein kinase C; PLC, phospholipase C. 


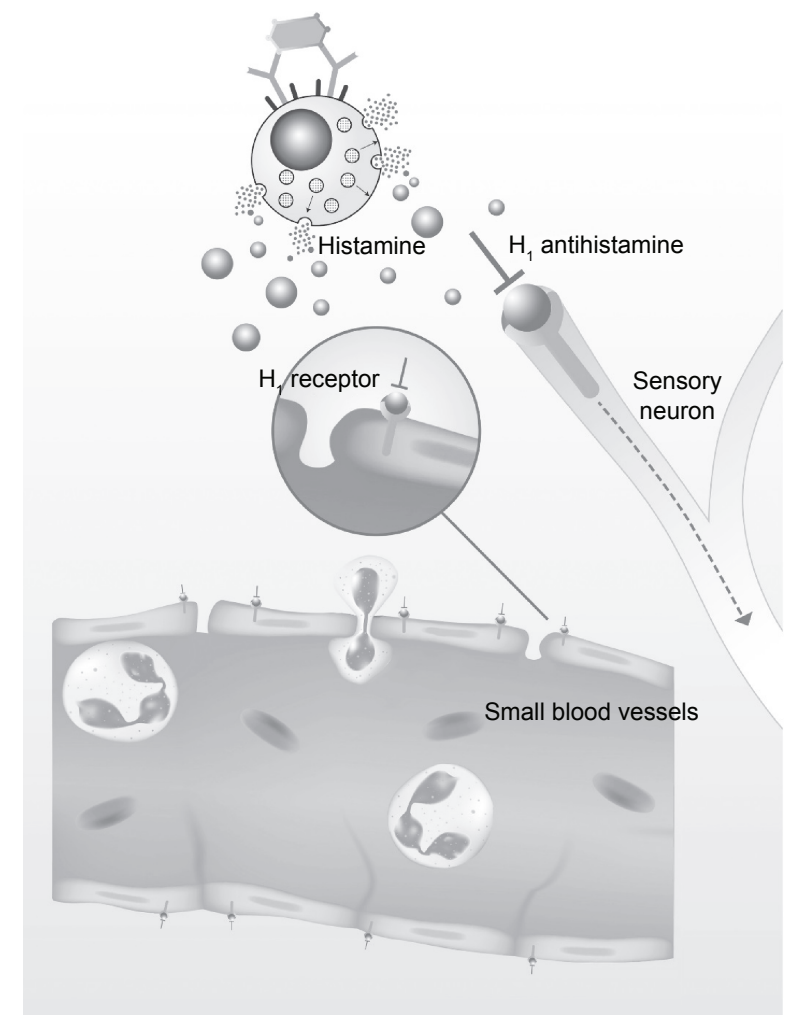

Figure 2 Direct downregulation of allergic inflammation by $H_{1}$ antihistamines.

to $H_{1}$ receptors; rather, antihistamines bind to different sites from histamine on $\mathrm{H}_{1}$ receptors. ${ }^{5}$ Therefore, these antihistamines are inverse agonists rather than receptor antagonists. 5,31,32 They are referred to as " $\mathrm{H}_{1}$ antihistamines" rather than "histamine antagonists". 5

When $\mathrm{H}_{1}$ antihistamines are bound to $\mathrm{H}_{1}$ receptors, they interfere with histamine action on sensory neurons and small blood vessels, directly downregulating allergic inflammation (Figure 2). This downregulation also takes place indirectly through transcription factor nuclear factor- $\kappa \mathrm{B}$ and through calcium ion channels. ${ }^{33}$

\section{History of antihistamines}

Histamine was discovered in 1907 by Windaus and Vogt, after decarboxylation of the amino acid histidine. ${ }^{33-35}$ Twenty years later, in 1927, Emanuel identified histamine as a constituent in normal tissues, notably the lungs, ${ }^{35}$ and in 1937, Bovet and Staub discovered antihistamines by demonstrating that synthesized agents could block the effects of histamine. ${ }^{36}$ A few years later, in 1942, the first antihistamine, phenbenzamine (Antergan), was introduced into commercial use. 5,33,34 This was closely followed by diphenhydramine, brompheniramine, and chlorpheniramine in the mid-1940s, promethazine later that decade, and hydroxyzine in the $1950 \mathrm{~s} .{ }^{34,35}$
In 1957, Daniel Bovet received the Nobel Prize in Physiology or Medicine for his major therapeutic contribution. More specifically, this was for his discoveries that synthesized agents that inhibited the actions of various body substances, particularly on the vascular and musculoskeletal systems. ${ }^{37}$

A key scientific discovery in the 1960s was that there was more than one type of histamine receptor, and in 1966 , Ash and Schild suggested that the receptor blocked by antihistamines be called the $\mathrm{H}_{1}$ receptor, and agents blocking it be called $\mathrm{H}_{1}$ receptor antagonists. ${ }^{38}$

Second-generation $\mathrm{H}_{1}$ antihistamines were introduced in the 1980s. These agents represented a major enhancement in antihistamine development because they had no or only minimal sedative activity. ${ }^{5}$ Furthermore, they were highly selective for $\mathrm{H}_{1}$ receptors and were devoid of anticholinergic activity. ${ }^{5}$ However, because of differences in drug specificity for active transporter proteins (eg, $P$-glycoprotein $[P$-gP $]$ ) across the blood-brain barrier, some second-generation agents may enter the CNS to a greater extent than others. ${ }^{5,39}$ Cetirizine, desloratadine, and loratadine, especially at high dosages, are potentially more sedating than fexofenadine and levocetirizine. . $^{5,40}$

Another major drawback for some second-generation agents was documentation in the late 1990s of significant cardiotoxicity. That is, astemizole and terfenadine were shown to block the delayed rectifier $\mathrm{K}^{+}$current $\left(I_{\mathrm{Kr}}\right)$, which is essential for cardiac repolarization. ${ }^{5}$ This gave rise to the potential for QT interval prolongation and life-threatening ventricular arrhythmias such as torsade de pointes. Such cardiotoxic potential is now well established and has been extensively reviewed. ${ }^{5}$ In most countries, astemizole and terfenadine have now been withdrawn from the market. ${ }^{4,5,41,42}$

The evolution of second-generation antihistamines was essentially based on experimentation with, and modification of, forerunning first-generation compounds. Further modifications then led to the introduction of other second-generation agents: for example, stereoselective investigation led to levocetirizine, and the knowledge of metabolism pathway of loratadine led to the development of desloratadine. A recent development is the dual platelet activator factor and histamine $H_{1}$ receptor antagonist rupatadine, ${ }^{43}$ which undergoes extensive hepatic metabolism to produce active metabolites, including desloratadine. ${ }^{43,44}$

However, bilastine (Figure 3) is a novel, benzimidazole-piperidine derivative that is a highly selective $\mathrm{H}_{1}$ antihistamine. ${ }^{45,46}$ Unlike certain other antihistamines, it is a distinct chemical entity and not derived structurally from other compounds in this class. ${ }^{32,47}$ It has been commercially available internationally since March 2011 . $^{48}$ 


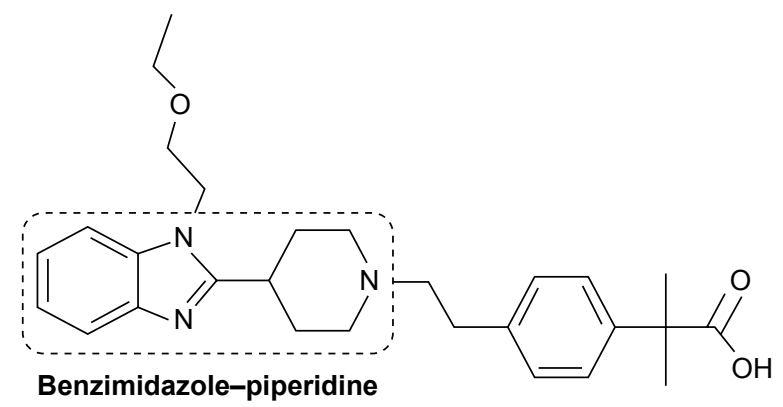

Figure 3 Chemical structure of bilastine.

\section{Properties of the "ideal" antihistamine}

The ARIA guidelines stipulate that before a physician prescribes pharmacotherapy, the following pertinent factors should be considered: the efficacy, safety and costeffectiveness of treatment, patient preference, the goals of treatment, anticipated adherence to treatment, disease severity, and control, as well as the presence of concurrent conditions. ${ }^{6}$ An extension of this is that the guidelines also provide a detailed list of "properties that should be met by oral $\mathrm{H}_{1}$-antihistamines" (Table 1). Fundamental among these properties are potent and selective blocking activity at $\mathrm{H}_{1}$ receptors, a rapid onset and long duration of action, efficacy in allergic rhinoconjunctivitis, and against all symptoms, including nasal obstruction, no interaction with cytochrome P450 (CYP 450), no sedative activity or cognitive or psychomotor impairment, no anticholinergic activity, no cardiac safety concerns, and no potential for tachyphylaxis. ${ }^{6}$

As outlined in the following sections, bilastine - as a modern, second-generation $\mathrm{H}_{1}$ antihistamine - has the highest number of desired features for a modern antihistamine according to international ARIA guidelines (Table 2).

\section{Bilastine pharmacology Preclinical trials}

For any new chemical entity with potential for therapeutic use, initial in vitro and in vivo preclinical studies are needed to fully characterize the compound's pharmacological profile. If efficacy is confirmed, and no major safety or toxicity concerns are identified, progression can continue to phase I clinical studies in healthy volunteers and then to Phase II-III clinical trials in the proposed indication.

With novel antihistamines (eg, bilastine), a specific goal of in vitro studies is to confirm that the test agent has marked selectivity - high affinity for histamine $\mathrm{H}_{1}$ receptors, but minimal effects at receptors for other mediators and amines. ${ }^{39}$ Thus, bilastine (inhibition constant $\left[K_{\mathrm{i}}\right] 44 \mathrm{nM}$ ) was shown to dose-dependently inhibit ${ }^{3} \mathrm{H}$-pyrilamine binding to $\mathrm{H}_{1}$ receptors in the guinea pig cerebellum, with an affinity approximately threefold greater than that of cetirizine $\left(K_{\mathrm{i}} 143 \mathrm{nM}\right)$ and fivefold greater than that of fexofenadine $\left(K_{\mathrm{i}} 246 \mathrm{nM}\right) .{ }^{49}$ Similar findings were obtained in a human embryonic kidney cell line (Figure $4 ; K_{\mathrm{i}} 64 \mathrm{nM}$ ). ${ }^{49}$ Additional in vitro trials demonstrated that bilastine had no significant antagonist activity at a diverse range of other receptors: $\mathrm{H}_{2}, \mathrm{H}_{3}$, and $\mathrm{H}_{4}, 5-\mathrm{HT}_{2 \mathrm{~A}}$, bradykinin $\mathrm{B}_{1}$, leukotriene $\mathrm{D}_{4}$, N-type voltagedependent calcium receptors, $\alpha_{1}$ - and $\beta_{2}$-adrenoceptors, and $\mathrm{M}_{1}-\mathrm{M}_{5}$ muscarinic receptors. ${ }^{39,49}$

In in vivo studies, bilastine showed antihistaminic activity in various animal models and produced the following effects: reduced histamine-induced capillary permeability in rats,

Table I Requirements of the ideal oral $\mathrm{H}_{1}$ antihistamine

\begin{tabular}{|c|c|c|}
\hline Pharmacological properties & Efficacy & Side effects \\
\hline Potent and selective activity at $\mathrm{H}_{1}$ receptors & Effective in both intermittent & No sedation or cognitive or psychomotor \\
\hline Other antiallergic activity & and persistent allergic rhinitis & impairment \\
\hline No clinically relevant pharmacokinetic interactions with & Effective against all nasal & No anticholinergic activity \\
\hline food, medication, or intestinal proteins & symptoms, including obstruction & No weight gain \\
\hline No interaction with cytochrome P450 & Improves ocular symptoms & No cardiac safety concerns \\
\hline No interaction with other diseases (thereby avoiding & Studies should be conducted & Potential use in pregnancy and breastfeeding \\
\hline \multirow[t]{4}{*}{ toxic reactions) } & in young children and elderly & Studies should be conducted in young children \\
\hline & patients to assess efficacy & and elderly patients to assess safety \\
\hline & & Prospective postmarketing safety analyses \\
\hline & & should be performed \\
\hline \multicolumn{3}{|l|}{ Pharmacodynamics } \\
\hline \multicolumn{3}{|l|}{ Rapid onset of action } \\
\hline \multicolumn{3}{|l|}{ Long duration of action permitting once-daily dosing } \\
\hline No potential for tolerance development (tachyphylaxis) & & \\
\hline
\end{tabular}

Note: Reproduced from Bousquet J, Khaltaev N, Cruz AA, et al; World Health Organization; GA(2)LEN; AllerGen. Allergic rhinitis and its impact on asthma (ARIA) 2008 update (in collaboration with the World Health Organization, GA(2)LEN and AllerGen). Allergy. 2008;63(suppl 86):8-160. ${ }^{6}$ With permission from John Wiley and Sons. Copyright @2008. 


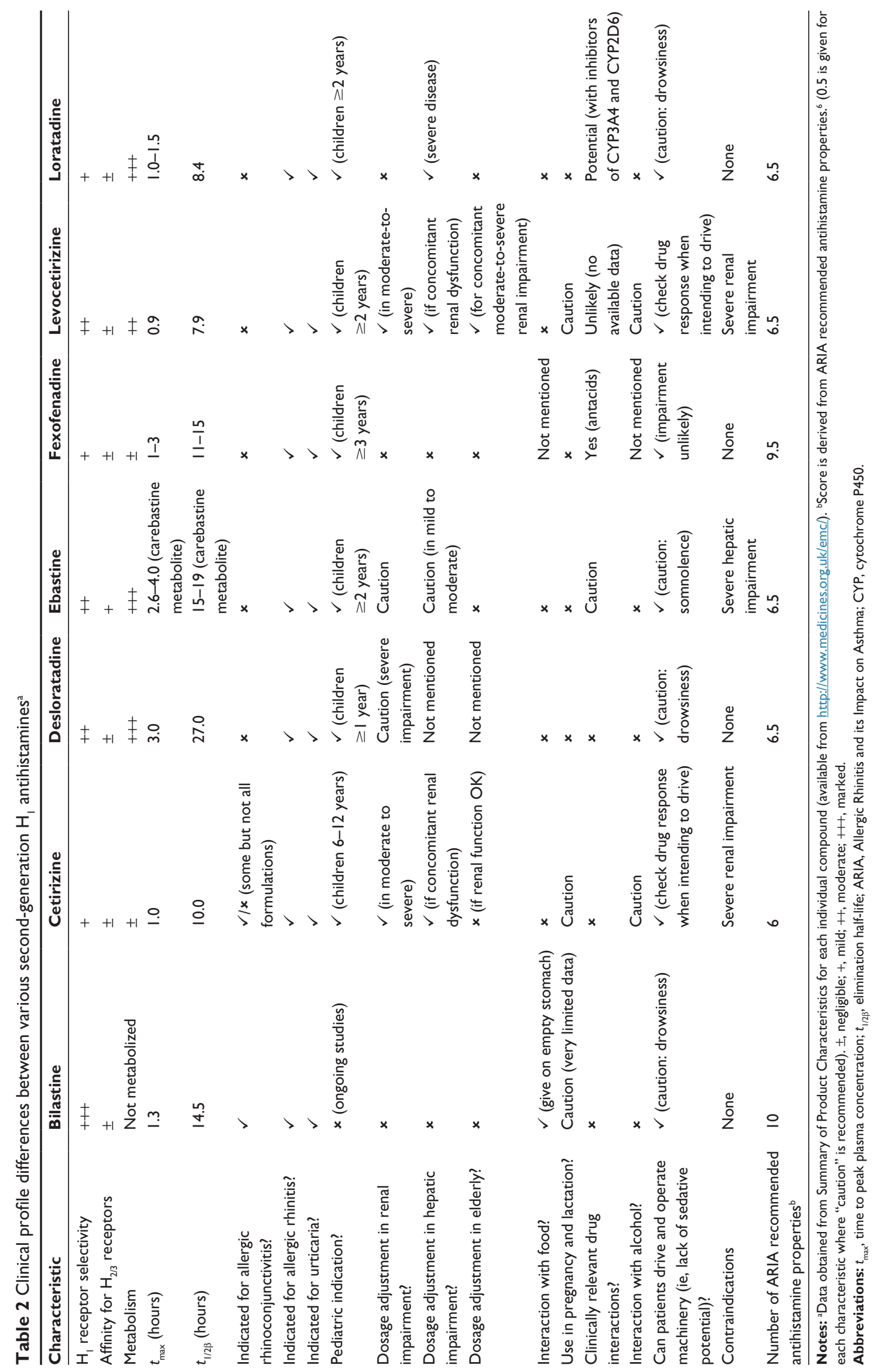


reduced microvascular leakage from guinea pig trachea and rat dorsal skin, and reduced histamine-induced bronchospasm and histamine- and compound 48/80-induced lethality in guinea pigs. ${ }^{31,50}$ In these respects, bilastine had effects similar to those of cetirizine but was more potent than fexofenadine..$^{31,50}$

Other antiallergic effects of bilastine were demonstrated in various rodent models. Specifically, bilastine reduced vascular permeability mediated by passive cutaneous anaphylaxis in rats and reduced IgG-dependent active cutaneous anaphylaxis. In mice, bilastine reduced IgE-dependent active cutaneous anaphylaxis and the passive Arthus reaction induced by ovine red blood cells. ${ }^{50}$ Again, the magnitude of these effects was similar to that produced by cetirizine and superior to that produced by fexofenadine. ${ }^{50}$

\section{Pharmacokinetic profile}

Bilastine is rapidly absorbed after oral administration. ${ }^{51}$ In rats, its onset of antihistaminic action is $\sim 30$ minutes postdose, the maximum clinical effect persists from 30 minutes to 8 hours postdose, and the drug has a prolonged duration of action ( $\geq 16$ hours; Figure 5). ${ }^{51}$

In healthy volunteers given a single oral dose of bilastine $20 \mathrm{mg}$, the mean peak plasma concentration $\left(C_{\max }\right)$ was $220 \mu \mathrm{g} / \mathrm{L}$, attained at 1.3 hours postdose $\left(t_{\max }\right) \cdot{ }^{51}$ The apparent volume of distribution $\left(V_{\mathrm{d}}\right)$ was $1.29 \mathrm{~L} / \mathrm{kg}$, terminal elimination half-life $\left(t_{1 / 2 \beta}\right)$ was 14.5 hours, and total plasma clearance was $18.1 \mathrm{~L} / \mathrm{h}$; bilastine was $84 \%-90 \%$ bound to plasma proteins. ${ }^{51}$

The oral bioavailability of bilastine is $\sim 60 \% .{ }^{52}$ However, in healthy volunteers given a single $20 \mathrm{mg}$ dose, concurrent food intake reduced bioavailability by $30 \%$ (high-fat meal) or $25 \%$ (low-fat meal) relative to fasting conditions. ${ }^{48}$ Concomitant ingestion of grapefruit juice also reduced

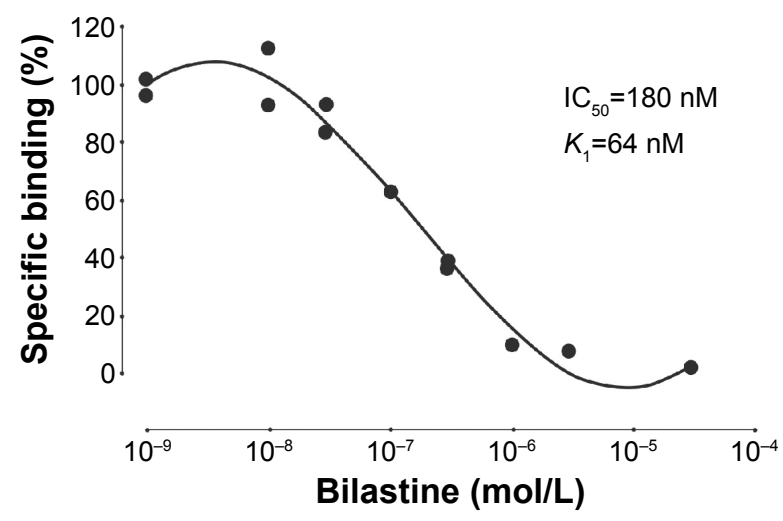

Figure 4 Affinity of bilastine to human $\mathrm{H}_{1}$ receptors expressed in HEK-293 cell. Note: Reproduced from Drugs $R D$, A Preclinical pharmacology of bilastine, a new selective histamine $H_{1}$ receptor antagonist: receptor selectivity and in vitro antihistaminic activity, 2005;6:37I-384, Corcostegui R, Labeaga L, Innerarity A Berisa A, Orjales A, ${ }^{49}$ Copyright $@ 2005$, With permission of Springer.

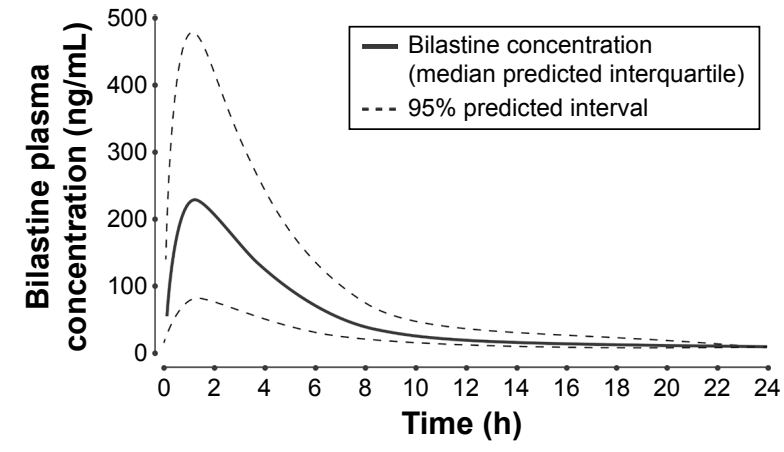

Figure 5 Predicted and observed plasma concentration-time profile after oral administration of a single $20 \mathrm{mg}$ dose of bilastine to healthy volunteers.

Note: Reproduced from Clin Pharmacokinet, Pharmacokinetic-pharmacodynamic modelling of the antihistaminic (HI) effect of bilastine, 2009;48:543-554, Jauregizar N, de la Fuente L, Lucero ML, Sologuren A, Leal N, Rodríguez M, ${ }^{51}$ Copyright @2009, With permission of Springer.

Abbreviation: h, hours.

bilastine bioavailability by $30 \%{ }^{48}$ Therefore, it is recommended that bilastine be taken in the fasting state. ${ }^{48}$

As previously outlined, and as listed in ARIA guidelines, ${ }^{6}$ one of the key qualities of an ideal oral $\mathrm{H}_{1}$ antihistamine is to have no interaction with CYP 450. However, some oral $\mathrm{H}_{1}$ antihistamines (eg, loratadine, rupatadine) are extensively transformed to active metabolites by the CYP system in the liver. This creates significant potential for drug-drug interactions. ${ }^{7}$ Importantly, bilastine does not interact significantly, either as an inhibitor or as a inducer, with the CYP enzyme system in vitro, ${ }^{53}$ and it does not undergo significant metabolism in humans ${ }^{48}$ Approximately $95 \%$ of an oral bilastine dose is excreted unchanged in the urine $(28 \%)$ and feces $(67 \%){ }^{48}$ This elimination profile markedly reduces the potential for metabolic drug-drug interactions.

Oral bilastine can be administered to patients independently of glomerular filtration rate. ${ }^{54}$ No dosage adjustments are needed in patients with mild, moderate, or severe renal impairment. ${ }^{54}$ However, in patients with moderate-severe renal insufficiency who are being treated with P-gP inhibitors, such as cyclosporine, diltiazem, erythromycin, ketoconazole, or ritonavir, bilastine should not be administered; these inhibitors may increase plasma bilastine levels and lead to increased potential for adverse events. ${ }^{48}$

As this agent is not metabolized and is excreted largely unchanged, hepatic impairment is not expected to increase systemic exposure above the safety margin of the drug. ${ }^{55}$ Therefore, no dosage adjustment is needed in patients with hepatic impairment. ${ }^{48}$

Bilastine is a substrate for several transporter proteins in the P-gP and organic anion-transporter protein class. These transporters have a significant influence on the 
pharmacokinetic profile of various drugs since P-gP can be considered as an efflux pump, whereas organic aniontransporter proteins can facilitate drug uptake. ${ }^{55}$ Bilastine has shown a high affinity for the P-gP efflux pump; ${ }^{55}$ this effect restricts transit across the blood-brain barrier and limits the potential for sedation. . $^{30,32}$

Differences between the transporter protein-binding profiles of second-generation antihistamines may explain some of the substantial differences in clinical activity and tolerability that exist between agents in this class (Table 2). Further research in this area is clearly warranted. Indeed, transporter protein interactions might ultimately explain important clinical differences, such as the potentially longer duration of action for bilastine over fexofenadine. ${ }^{56}$

\section{Bilastine efficacy}

The bilastine clinical trial program was designed before the publication of the 2001 ARIA guidelines, so the patient inclusion criteria were based on the former classification of seasonal and perennial allergic rhinitis.

\section{Seasonal allergic rhinitis}

In two multicenter, randomized, double-blind, placebocontrolled trials in a total of 1,402 patients with seasonal allergic rhinitis, the efficacy of bilastine was compared with that of cetirizine ${ }^{57}$ and desloratadine..$^{58}$

In one trial, ${ }^{57}$ over a 2 -week treatment period, bilastine and cetirizine displayed similar efficacy: both compounds significantly reduced total symptom score (TSS = nasal symptom score [NSS] + nonnasal symptom score [NNSS]), relative to placebo. ${ }^{57}$ The percentage decrease from baseline in NSS (for nasal obstruction, rhinorrhea, sneezing, and itching) was significantly greater $(P<0.001)$ with bilastine $(-42.4 \%)$ and cetirizine $(-48.2 \%)$ than placebo $(-26.9 \%)$. The same was true for NNSS (for ocular tearing, redness, and itching): corresponding percentage changes from baseline were $-49.8 \%,-51.0 \%$, and $-27.6 \%$ (Figure 6 ). ${ }^{57}$

In the other trial, ${ }^{58}$ similar results to the first study were obtained for bilastine and desloratadine versus placebo over a 2-week treatment period. Regarding the primary study end point - area under the curve of TSS $\left(\mathrm{AUC}_{\mathrm{TSS}}\right)$ - the mean value was significantly lower $(P<0.001)$ for bilastine $(98.4)$ and desloratadine (100.5) than for placebo (118.4). ${ }^{58}$

In a Vienna Challenge Chamber study performed outside the pollen season in 75 individuals with asymptomatic seasonal allergic rhinitis, an antihistamine or placebo was administered immediately before allergen challenge. ${ }^{56}$ The three antihistamines tested, bilastine, cetirizine, and

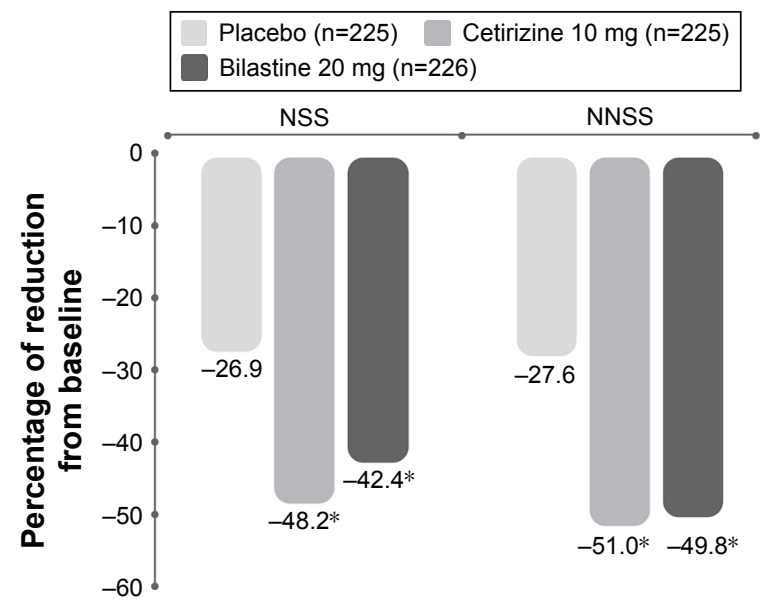

Figure 6 Percentage decrease from baseline in NSS and NNSS in a randomized, double-blind, placebo-controlled study of bilastine versus cetirizine in patients with seasonal allergic rhinitis.

Note: $* P<0.001$ versus placebo. Data from Kuna et al. ${ }^{57}$

Abbreviations: NSS, nasal symptom score; NNSS, nonnasal symptom score.

fexofenadine, were all significantly effective $(P<0.001)$ regarding percentage mean decrease in total NSS versus placebo at all time points, including early (1-4 hours) and late (22-26 hours) after dosing. ${ }^{56}$ However, at the latter time point, bilastine $(P=0.0012)$ and cetirizine $(P<0.001)$ were both significantly more effective than fexofenadine (Figure 7$).^{57}$ As already mentioned, this suggests that bilastine and cetirizine have a longer duration of action than fexofenadine. ${ }^{56}$

Bilastine is indicated for allergic rhinoconjunctivitis, whereas not all antihistamines have this specific indication (Table 2). An analysis of bilastine clinical trials showed that this agent was significantly more effective than placebo at relieving ocular symptoms $(P<0.001)$, including both

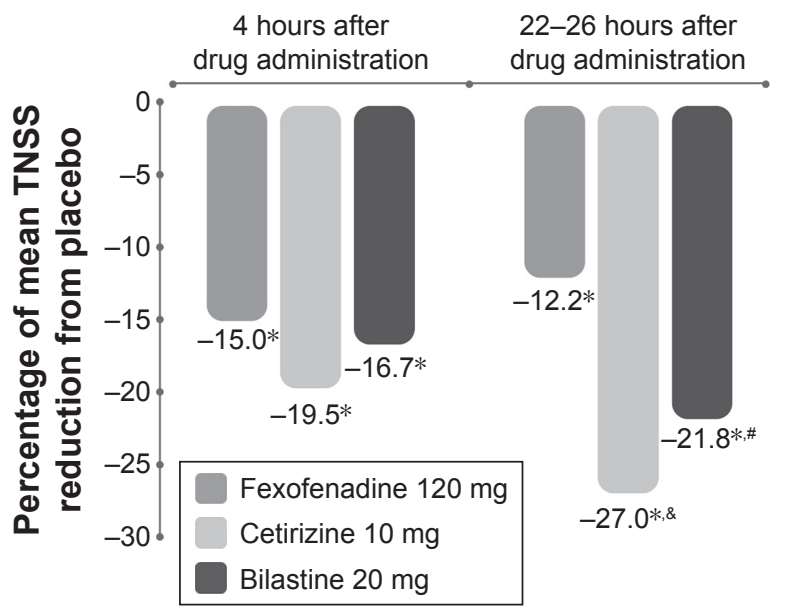

Figure 7 Effects of three antihistamines on TNSS in a Vienna Challenge Chamber study performed in 75 individuals with asymptomatic seasonal allergic rhinitis. Notes: $* P<0.001$ versus placebo, ${ }^{*} P=0.0012$ for bilastine versus fexofenadine, $\& P<0.00$ I for cetirizine versus fexofenadine. Data from Horak et al. ${ }^{56}$

Abbreviation: TNSS, total nasal symptom score. 
reflexive and instantaneous symptoms (itching, tearing, and conjunctival redness). ${ }^{59}$

\section{Perennial allergic rhinitis}

A randomized, double-blind, placebo-controlled trial, conducted in Europe, Argentina, and South Africa, compared the efficacy of bilastine with that of cetirizine and placebo over 4 weeks in 651 patients with perennial allergic rhinitis; in an open-label, extension phase, 513 patients were treated with bilastine $20 \mathrm{mg}$ once daily for 12 months, ${ }^{60}$ the longest analysis to date with any antihistamine. There was no statistically significant difference between groups in $\mathrm{AUC}_{\mathrm{TSS}}$ from baseline to day $28 .{ }^{60}$ However, there was a region-specific effect: primary efficacy was significantly better in the antihistamine versus placebo groups in Europe and Argentina $(P=0.039)$. Conversely, no significant difference was evident in South Africa, where patients reported a relatively high placebo response rate. ${ }^{60}$ During the open-label extension phase, bilastine significantly reduced TSS, NSS, NSS without blocked symptoms, NNSS, and constituent symptoms after both the patients' and investigators' assessments. ${ }^{60}$ The longterm extension phase of this study also demonstrated that bilastine was safe and well tolerated during extended use. ${ }^{60}$

The proven efficacy of bilastine in perennial allergic rhinitis is important for physicians in the Southeast Asian region, given the high proportion of patients who have persistent allergic rhinitis in this part of the world..$^{15,16}$

\section{Urticaria}

A 4-week, multicenter, randomized, double-blind, placebocontrolled study compared the efficacy of bilastine with that of levocetirizine in a total of 525 patients with chronic idiopathic urticaria. ${ }^{61}$ Bilastine and levocetirizine were similarly effective and both significantly more effective than placebo $(P<0.001)$, in reducing mean TSS (for pruritus severity, number of wheals, and maximum size of wheals) over 2 weeks and 4 weeks (Figure 8). ${ }^{61}$ Significantly greater improvements than placebo were noted regarding reduction in Dermatology Life Quality Index score: bilastine $-9.45(P<0.001)$, levocetirizine $-8.94(P<0.001)$, and placebo $-5.93 .{ }^{61}$

Bilastine is more effective than cetirizine at limiting the early allergic response, according to the results of a study in volunteers. ${ }^{62}$ Volunteers received a single oral dose of bilastine $20 \mathrm{mg}$, cetirizine $10 \mathrm{mg}$, or placebo, before provocation of a cutaneous wheal and flare response. At 1.5 hours after the provocation, there was significantly greater inhibition of the wheal and flare response among those who received bilastine than in those who received cetirizine or placebo $(P<0.02){ }^{62}$

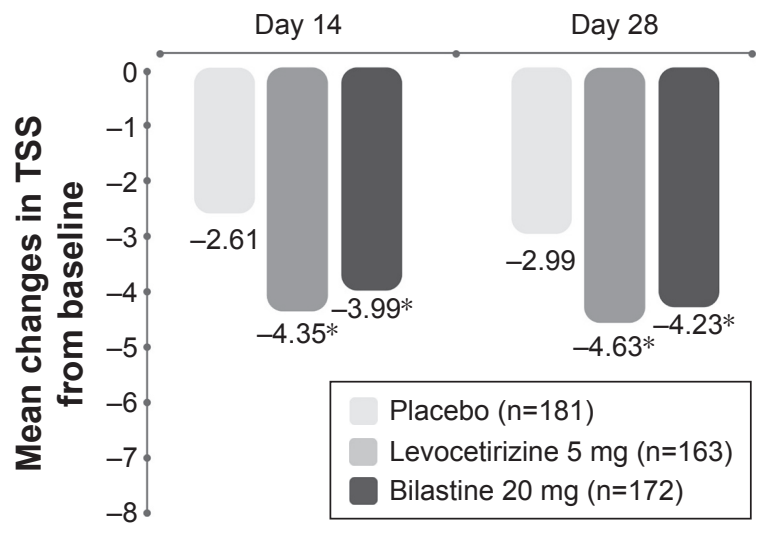

Figure 8 Mean decreases in TSS during 4 weeks' administration of bilastine or levocetirizine to patients with chronic spontaneous urticaria.

Notes: $* P<0.001$ versus placebo. Reproduced from Zuberbier T, Oanta A, Bogacka E, et al; Bilastine International Working Group. Comparison of the efficacy and safety of bilastine $20 \mathrm{mg}$ vs levocetirizine $5 \mathrm{mg}$ for the treatment of chronic idiopathic urticaria: a multi-centre, double-blind, randomized, placebo-controlled study. Allergy. 2010;65:516-528. ${ }^{61}$ With permission from John Wiley and Sons. Copyright (C2009.

Abbreviation: TSS, total symptom score.

While spontaneous urticaria is the most common form, ${ }^{23,63} \sim 25 \%$ of patients with urticaria have an inducible form. Bilastine has been evaluated at a range of doses, from the recommended dose of $20 \mathrm{mg}$ to four times this dosage (ie, $80 \mathrm{mg}$ once daily) in a randomized, double-blind, placebocontrolled, 7-day study in patients with acquired cold urticaria. A response rate (percentage of patients symptom free) of $60 \%$ was obtained. ${ }^{64}$ The incidence of adverse events at all bilastine doses ( $20 \mathrm{mg}, 40 \mathrm{mg}$, and $80 \mathrm{mg}$ ) was similar to placebo, ${ }^{64}$ demonstrating that bilastine is well tolerated even at doses two or four times higher than the recommended daily dose. Further research is needed to demonstrate its efficacy in other inducible forms of urticaria, which may include urticaria induced by pressure, heat, sun exposure, exercise, or contact with specific allergens.

The use of supratherapeutic doses of bilastine in the study of patients with cold urticaria is consistent with international guideline recommendations. Joint guidelines from the European Academy of Allergy and Clinical Immunology (EAACI), the Global Allergy and Asthma European Network (GA²LEN), the European Dermatology Forum (EDF), and the World Allergy Organization (WAO) now clearly stipulate that "modern second generation $\mathrm{H}_{1}$-antihistamines are to be used as first line treatment of urticaria." In addition, these guidelines recommend "a trial of up to fourfold dose of modern second generation $\mathrm{H}_{1}$-antihistamines as second-line in the algorithm of treatment." The aim of this recommendation is to attain complete control of symptoms ${ }^{4}$ since more than one-third of patients with chronic urticaria are refractory to standard-dosage antihistamine therapy. ${ }^{11}$ 
A comparison of clinical trial data for second-generation antihistamines in chronic urticaria suggests that this bilastine dosage $(80 \mathrm{mg} / \mathrm{d})$ is significantly more effective than supratherapeutic dosages of desloratadine and levocetirizine (Figure 9). ${ }^{22}$ However, use of these compounds at four times higher than standard doses is certain to raise safety concerns among some physicians. For instance, the sedative potential of cetirizine, desloratadine, and loratadine will likely be markedly greater than that of bilastine, fexofenadine, and levocetirizine. ${ }^{5,40}$ Concerns at high dosage may also manifest about the potential for QTc prolongation, particularly given the unfavorable history of astemizole and terfenadine. ${ }^{31}$ However, bilastine at therapeutic and supratherapeutic doses in healthy volunteers had no significant influence on ventricular repolarization. Bilastine doses of $20 \mathrm{mg}$ and $100 \mathrm{mg}$ had no clinically significant effect on QTc interval. Bilastine $20 \mathrm{mg}$ was also administered with ketoconazole and had no effect on QTc interval when used in combination. ${ }^{42}$

\section{Bilastine safety}

The safety database for bilastine comprises $>5,000$ individuals involved in well-designed clinical trials. A total of $>3,000$ patients were treated with bilastine, generally at a dosage of $20 \mathrm{mg}$ once daily for 2-4 weeks. ${ }^{39}$ The incidence of treatment-related adverse events was not markedly different between bilastine (12.7\%), placebo (12.8\%), and other antihistamines: cetirizine (14.3\%), desloratadine (11.6\%), and levocetirizine $(15.8 \%) .{ }^{39}$

In the pooled analysis of adverse events, the incidence of treatment-related CNS events was similar between bilastine and placebo. Headache and dizziness showed a similar incidence between all active treatment and placebo groups.

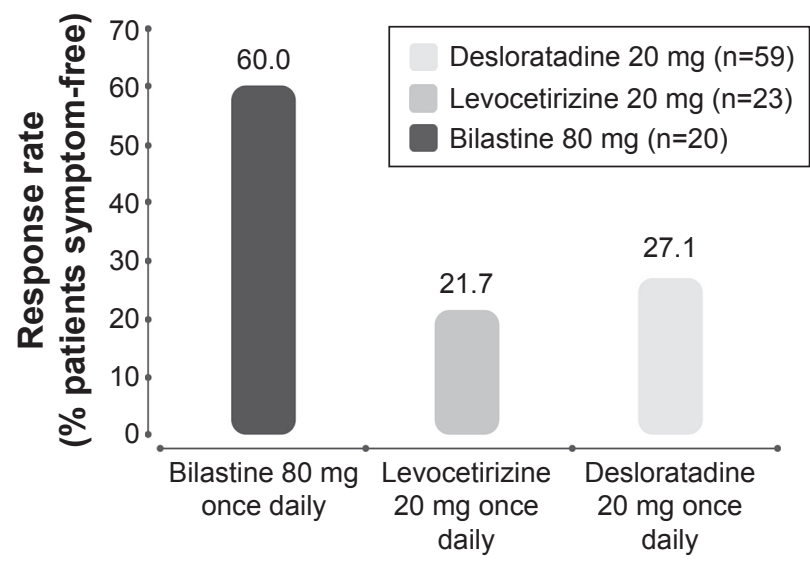

Figure 9 Efficacy of increased dosages of second-generation antihistamines in chronic urticaria.

Note: Adapted from Sanchez-Borges M, Ansotegui I, Jimenez JM, Rojo MI, Serrano C, Yañez A. Comparative efficacy of non-sedating antihistamine updosing in patients with chronic urticaria. World Allergy Organ J. 2014;7:33. ${ }^{22}$
Somnolence occurred with a similar frequency in bilastine (3.5\%) and placebo recipients (2.9\%). However, cetirizine was associated with a significantly greater incidence of somnolence (7.6\%, $P<0.001)$ than bilastine and levocetirizine with a significantly greater incidence $(6.1 \%, P<0.05)$ than placebo. ${ }^{39}$

In a large-scale, randomized, double-blind study in a total of 683 patients with seasonal allergic rhinitis, bilastine versus cetirizine was linked with a significantly smaller incidence of all drug-related events ( $14.5 \%$ vs $24.6 \%, P \leq 0.01)$, fatigue $(0.4 \%$ vs $4.8 \%, P \leq 0.01)$, and somnolence $(1.8 \%$ vs $7.5 \%) .{ }^{57}$ The clear implication from these data is that, in everyday clinical practice, bilastine has a better safety profile and therapeutic index than cetirizine.

High-dosage bilastine (40 $\mathrm{mg}$ or $80 \mathrm{mg}$ once daily), in line with EAACI/GA ${ }^{2} \mathrm{LEN} / \mathrm{EDF} / \mathrm{WAO}$ guidelines, ${ }^{4}$ has demonstrated efficacy in the treatment of urticaria. ${ }^{64}$ In a study in patients with acquired cold urticaria, bilastine was well tolerated without evidence of an increased incidence of sedation at doses up to $80 \mathrm{mg} /$ day. $^{64}$

The CNS effects of bilastine $80 \mathrm{mg}$ were also evaluated in healthy volunteers. ${ }^{65}$ Although objective test results ( $\mathrm{d} 2$ cancellation test, simple reaction time) revealed minor - yet significant-impairment, high-dosage bilastine did not significantly alter subjective test results (visual analog scale score, Profile of Mood States questionnaire score). ${ }^{65}$ The effects of bilastine $80 \mathrm{mg}$ were equivalent to those of standard-dose hydroxyzine. ${ }^{65}$

\section{Lack of sedation}

In several studies utilizing an active control "arm" comprising the first-generation agent hydroxyzine, standard-dosage bilastine (20 mg once daily) and higher-dosage bilastine (40 mg once daily in one study ${ }^{66}$ and a single $80 \mathrm{mg}$ dose in another ${ }^{65}$ ) had no significant effects on various objective measures of psychomotor and driving performance. ${ }^{65,66}$ Moreover, when bilastine was administered concurrently with lorazepam, the extent of psychomotor impairment was similar to that when lorazepam was administered alone. ${ }^{39}$ Also, no interaction has been identified between alcohol and standard-dosage bilastine. Objective testing in a placebo-controlled trial revealed an extent of psychomotor impairment with bilastine $20 \mathrm{mg}+$ alcohol similar to that noted after ingestion of alcohol alone, whereas standard doses of either hydroxyzine or cetirizine exacerbated the impairing effects of alcohol on psychomotor performance. ${ }^{65}$

A positron emission tomography study of brain $\mathrm{H}_{1}$ receptor occupancy in 12 healthy volunteers revealed that this 
parameter was close to zero for bilastine $(-3.92 \%)$, and therefore similar to placebo. Conversely, the first-generation agent hydroxyzine had significantly greater occupancy $(+54 \%) .{ }^{67,68}$ This confirms that bilastine has relatively limited potential to cross the blood-brain barrier and interact with $\mathrm{CNS}_{1}$ receptors. Based on published data for other agents, it appears that bilastine has the lowest rate of brain $\mathrm{H}_{1}$ receptor occupancy of all the available antihistamines (Table 3). ${ }^{67,69-73}$ Therefore, it has minimal capacity to cause CNS adverse effects.

\section{No QTc prolongation}

The cardiac safety profile of bilastine was confirmed in various studies that included concurrent administration of the CYP450/P-gP inhibitors ketoconazole, erythromycin, and diltiazem and in detailed QT studies ${ }^{40,74}$ conducted in accordance with International Conference on Harmonization (ICH) guidelines. To date, bilastine is the only commercially available antihistamine that has been tested using the stringent $\mathrm{ICH}$ E/14 criteria for effects on QT interval. This study showed no significant effect on QTc interval using these stringent criteria. $^{42,69}$ These studies confirmed that standard-dosage bilastine has a good cardiac safety profile and that uptitration of the bilastine dose to $220 \mathrm{mg}$, or administration of the drug with CYP450 or P-gP inhibitors, does not alter this safety profile. ${ }^{42,69}$ In clinical trials, bilastine was not associated with any clinically relevant QTc interval prolongation. ${ }^{39}$

\section{Bilastine administration in children}

The efficacy and safety of bilastine in children aged 12 years or less, who frequently have allergic disorders, have not yet been established. For registration of the adult formulation of bilastine, the clinical plan was developed to comply with the European Medicines Agency guidelines and therefore the cut off age is 12 years. However, bilastine has been

Table 3 Percentage of brain $\mathrm{H}_{1}$ receptor occupancy (mean) after oral administration of antihistamines using $\mathrm{PET}^{67,69-73}$

\begin{tabular}{lll}
\hline & Dose (mg) & $\begin{array}{l}\text { Mean H, receptor } \\
\text { occupancy on PET (\%) }\end{array}$ \\
\hline Bilastine $^{67}$ & 20 & -3.92 \\
Fexofenadine $^{73}$ & 120 & -0.1 \\
Ebastine $^{72}$ & 10 & $9.9-14.4$ \\
Terfenadine $^{69,70}$ & 60 & $12.1-17.2$ \\
Azelastine $^{70}$ & 1 & 20.3 \\
Cetirizine $^{73}$ & 20 & 26.0 \\
d-Chlorpheniramine $^{71}$ & 1 & 40.4 \\
Hydroxyzine $^{67}$ & 25 & 53.95 \\
d-Chlorpheniramine $^{69-71}$ & 2 & $60.4-76.8$ \\
d-Chlorpheniramine $^{71}$ & 5 & 85.5 \\
\hline
\end{tabular}

Abbreviation: PET, positron emission tomography. investigated according to a Paediatric Investigation Plan that was designed according to the requirements of the European Medicines Agency Paediatric Committee. Publication of data from the Paediatric Investigation Plan is awaited with interest.

\section{Conclusion}

Currently, there are a number of unmet needs in the management of allergic conditions in Asia Pacific, ${ }^{14,75}$ with many patients still experiencing sedation from the use of older antihistamines. ${ }^{68}$ When second-generation $\mathrm{H}_{1}$ antihistamines were introduced in the 1980s, they revolutionized the treatment of allergic disorders because of a lack of, or only minimal, sedative potential. ${ }^{39}$

The proven efficacy and safety profile of bilastine, its low potential for CNS impairment when coadministered with alcohol or for metabolic drug-drug interactions, and no need for dose adjustments confirm that this compound has a forerunning place in therapy among second-generation $\mathrm{H}_{1}$ antihistamines in the management of urticaria and allergic rhinitis, including allergic rhinoconjunctivitis (intermittent and persistent).

\section{Acknowledgments}

The authors would like to acknowledge Menarini AsiaPacific Holdings Pte Ltd for providing logistic support and funding for the consensus meeting and for commissioning MIMS Pte Ltd to provide writing assistance and editorial support. The views expressed in this manuscript are solely those of the authors.

\section{Disclosure}

The authors report no conflicts of interest in this work.

\section{References}

1. Pawankar R, Canonica GW, Holgate ST, Lockey RF, Blaiss MS. WAO White Book on Allergy: Update 2013. Milwaukee, WI: World Allergy Organization; 2013.

2. Kumar Y, Bhatia A. Immunopathogenesis of allergic disorders: current concepts. Expert Rev Clin Immunol. 2013;9:211-226.

3. Brozek JL, Bousquet J, Baena-Cagnani CE, et al; Global Allergy and Asthma European Network; Grading of Recommendations Assessment, Development and Evaluation Working Group. Allergic rhinitis and its impact on asthma (ARIA) guidelines: 2010 revision. J Allergy Clin Immunol. 2010;126:466-476.

4. Zuberbier T, Aberer W, Asero R, et al; European Academy of Allergy and Clinical Immunology; Global Allergy and Asthma European Network; European Dermatology Forum; World Allergy Organization. The EAACI/GA(2) LEN/EDF/WAO guideline for the definition, classification, diagnosis, and management of urticaria: the 2013 revision and update. Allergy. 2014;69:868-887.

5. Church DS, Church MK. Pharmacology of antihistamines. World Allergy Organ J. 2011;4(3 suppl):S22-S27. 
6. Bousquet J, Khaltaev N, Cruz AA, et al; World Health Organization; GA(2)LEN; AllerGen. Allergic rhinitis and its impact on asthma (ARIA) 2008 update (in collaboration with the World Health Organization, GA(2)LEN and AllerGen). Allergy. 2008;63(suppl 86):8-160.

7. Bousquet J, Schunemann HJ, Samolinski B, et al; World Health Organization Collaborating Center for Asthma and Rhinitis. Allergic rhinitis and its impact on asthma (ARIA): achievements in 10 years and future needs. J Allergy Clin Immunol. 2012;130:1049-1062.

8. Bousquet J, Van Cauwenberge P, Khaltaev N; Aria Workshop Group; World Health Organization. Allergic rhinitis and its impact on asthma. J Allergy Clin Immunol. 2001;108(5 suppl):S147-S334.

9. Angier E, Willington J, Scadding G, et al; British Society for Allergy \& Clinical Immunology (BSACI) Standards of Care Committee. Management of allergic and non-allergic rhinitis: a primary care summary of the BSACI guideline. Prim Care Respir J. 2010;19:217-222.

10. Canonica GW, Bousquet J, Mullol J, Scadding GK, Virchow JC. A survey of the burden of allergic rhinitis in Europe. Allergy. 2007;62(suppl 85): $17-25$.

11. Meltzer EO, Blaiss MS, Naclerio RM, et al. Burden of allergic rhinitis: allergies in America, Latin America, and Asia-Pacific adult surveys. Allergy Asthma Proc. 2012;33(suppl 1):S113-S141.

12. Annesi-Maesano I, Beyer A, Marmouz F, Mathelier-Fusade P, Vervloet D, Bauchau V. Concurrent allergic diseases: a cross-sectional study in a French population. Allergy. 2006;61:390-391.

13. Blaiss MS. Allergic rhinitis: direct and indirect costs. Allergy Asthma Proc. 2010;31:375-380.

14. Prepageran N. Managing allergic rhinitis and chronic rhinosinusitis in developing countries - focus on Asia Pacific. In: Akdis CA, Hellings PW, Agache I, editors. Global Atlas of Allergic Rhinitis and Chronic Sinusitis. Zurich: European Academy of Allergy and Clinical Immunology; 2015:400-403.

15. Asha'ari ZA, Yusof S, Ismail R, Che Hussin CM. Clinical features of allergic rhinitis and skin prick test analysis based on the ARIA classification: a preliminary study in Malaysia. Ann Acad Med Singapore. 2010;39:619-624.

16. Bunnag C, Jareoncharsri P, Tantilipikorn P, Vichyanond P, Pawankar R. Epidemiology and current status of allergic rhinitis and asthma in Thailand - ARIA Asia-Pacific Workshop report. Asian Pac J Allergy Immunol. 2009;27:79-86.

17. Zhang L, Han D, Huang D, et al. Prevalence of self-reported allergic rhinitis in eleven major cities in China. Int Arch Allergy Immunol. 2009; 149:47-57.

18. Zuberbier T. Urticaria. Allergy. 2003;58:1224-1234.

19. Ferrer M, Sastre J, Jauregui I, et al. Effect of antihistamine up-dosing in chronic urticaria. J Investig Allergol Clin Immunol. 2011;21(suppl 3): 34-39.

20. Muller BA. Urticaria and angioedema: a practical approach. Am Fam Physician. 2004;69:1123-1128.

21. Carstens E, Akiyama T. Itch: Mechanisms and Treatment. Boca Raton, FL: Frontiers in Neuroscience; 2014.

22. Sanchez-Borges M, Ansotegui I, Jimenez JM, Rojo MI, Serrano C, Yañez A. Comparative efficacy of non-sedating antihistamine updosing in patients with chronic urticaria. World Allergy Organ J. 2014;7:33.

23. Maurer M, Weller K, Bindslev-Jensen C, et al. Unmet clinical needs in chronic spontaneous urticaria. A GA(2)LEN task force report. Allergy. 2011;66:317-330.

24. Zuberbier T, Balke M, Worm M, Edenharter G, Maurer M. Epidemiology of urticaria: a representative cross-sectional population survey. Clin Exp Dermatol. 2010;35:869-873.

25. Staevska M, Gugutkova M, Lazarova C, et al. Night-time sedating H1-antihistamine increases daytime somnolence but not treatment efficacy in chronic spontaneous urticaria: a randomized controlled trial. Br J Dermatol. 2014;171:148-154.

26. Pawankar R, Holgate ST, Canonica GW, Lockey RF, Blaiss MS, editors. WAO White Book on Allergy: Update 2013, Executive Summary. Milwaukee, WI: World Allergy Organization; 2013.
27. Baiardini I, Giardini A, Pasquali M, et al. Quality of life and patients' satisfaction in chronic urticaria and respiratory allergy. Allergy. 2003; 58:621-623

28. Staubach P, Dechene M, Metz M, et al. High prevalence of mental disorders and emotional distress in patients with chronic spontaneous urticaria. Acta Derm Venereol. 2011;91:557-561.

29. Zazzali JL, Broder MS, Chang E, Chiu MW, Hogan DJ. Cost, utilization, and patterns of medication use associated with chronic idiopathic urticaria. Ann Allergy Asthma Immunol. 2012;108:98-102.

30. Mahdy AM, Webster NR. Histamine and antihistamines. Anaesth Intensive Care Med. 2014;15:5.

31. Bousquet J, Ansotegui I, Canonica GW, et al. Establishing the place in therapy of bilastine in the treatment of allergic rhinitis according to ARIA: evidence review. Curr Med Res Opin. 2012;28:131-139.

32. Ridolo E, Montagni M, Bonzano L, Incorvaia C, Canonica GW. Bilastine: new insight into antihistamine treatment. Clin Mol Allergy. 2015;13:1.

33. Simons FE, Simons KJ. Histamine and H1-antihistamines: celebrating a century of progress. $J$ Allergy Clin Immunol. 2011;128:1139-1150.

34. Figueroa K, Shankley N. One hundred years of histamine research. $A d v$ Exp Med Biol. 2010;709:1-9.

35. Emanuel MB. Histamine and the antiallergic antihistamines: a history of their discoveries. Clin Exp Allergy. 1999;29(suppl 3):1-11. [discussion 12]

36. Bovet D, Staub A. Action protectrice des ethers phenologiques au cours de l'intoxication histaminique. ACRS Soc Biol. (Paris). 1937; 124:527-549. French.

37. Janssens MM. Introduction. Second-generation antihistamines. Clin Rev Allergy. 1993;11:1-3.

38. Ash AS, Schild HO. Receptors mediating some of the actions of histamine. Br J Pharmacol. 1966;27:427-429.

39. Church MK. Safety and efficacy of bilastine: a new H(1)-antihistamine for the treatment of allergic rhinoconjunctivitis and urticaria. Expert Opin Drug Saf. 2011;10:779-793.

40. Wallace DV, Dykewicz MS, Bernstein DI, et al; Joint Task Force on Practice; American Academy of Allergy; Asthma \& Immunology; American College of Allergy; Asthma and Immunology; Joint Council of Allergy, Asthma and Immunology. The diagnosis and management of rhinitis: an updated practice parameter. J Allergy Clin Immunol. 2008; 122(2 suppl):S1-S84.

41. Estelle F, Simons R. H1-receptor antagonists: safety issues. Ann Allergy Asthma Immunol. 1999;83:481-488.

42. Tyl B, Kabbaj M, Azzam S, et al. Lack of significant effect of bilastine administered at therapeutic and supratherapeutic doses and concomitantly with ketoconazole on ventricular repolarization: results of a thorough QT study (TQTS) with QT-concentration analysis. J Clin Pharmacol. 2012;52:893-903.

43. Picado C. Rupatadine: pharmacological profile and its use in the treatment of allergic disorders. Expert Opin Pharmacother. 2006;7: 1989-2001.

44. Sun C, Li Q, Pan L, et al. Development of a highly sensitive LC-MS/MS method for simultaneous determination of rupatadine and its two active metabolites in human plasma: application to a clinical pharmacokinetic study. J Pharmaceut Biomed Anal. 2015;111:163-168.

45. Kowal K, DuBuske L. Bilastine as a potential treatment in allergic rhinitis. Am J Rhinol Allergy. 2014;28:312-316.

46. Davila I, Sastre J, Mullol J, et al. Effect of bilastine upon nasal obstruction. J Investig Allergol Clin Immunol. 2011;21(suppl 3):2-8.

47. Wolthers OD. Bilastine: a new nonsedating oral $\mathrm{H} 1$ antihistamine for treatment of allergic rhinoconjunctivitis and urticaria. Biomed Res Int. 2013;2013:626837.

48. Menarini Farmaceutica Internazionale SRL. Ilaxten $20 \mathrm{mg}$ Tablets: Summary of Product Characteristics. Buckinghamshire: Menarini Farmaceutica Internazionale SRL; 2012.

49. Corcostegui R, Labeaga L, Innerarity A, Berisa A, Orjales A. Preclinical pharmacology of bilastine, a new selective histamine H1 receptor antagonist: receptor selectivity and in vitro antihistaminic activity. Drugs R D. 2005;6:371-384. 
50. Corcostegui R, Labeaga L, Innerarity A, Berisa A, Orjales A. In vivo pharmacological characterisation of bilastine, a potent and selective histamine H1 receptor antagonist. Drugs R D. 2006;7:219-231.

51. Jauregizar N, de la Fuente L, Lucero ML, Sologuren A, Leal N, Rodríguez M. Pharmacokinetic-pharmacodynamic modelling of the antihistaminic (H1) effect of bilastine. Clin Pharmacokinet. 2009;48: 543-554.

52. Sadaba B, Gomez-Guiu A, Azanza JR, Ortega I, Valiente R. Oral availability of bilastine. Clin Drug Investig. 2013;33:375-381.

53. Lucero ML, Gonzalo A, Mumford R, Betanzos M, Alejandro A. An overview of bilastine metabolism during preclinical investigations. Drug Chem Toxicol. 2012;35(suppl 1):18-24.

54. Lasseter KC, Sologuren A, La Noce A, Dilzer SC. Evaluation of the single-dose pharmacokinetics of bilastine in subjects with various degrees of renal insufficiency. Clin Drug Investig. 2013;33:665-673.

55. Lucero ML, Gonzalo A, Ganza A, et al. Interactions of bilastine, a new oral H(1) antihistamine, with human transporter systems. Drug Chem Toxicol. 2012;35(suppl 1):8-17.

56. Horak F, Zieglmayer P, Zieglmayer R, Lemell P. The effects of bilastine compared with cetirizine, fexofenadine, and placebo on allergeninduced nasal and ocular symptoms in patients exposed to aeroallergen in the Vienna Challenge Chamber. Inflamm Res. 2010;59:391-398.

57. Kuna P, Bachert C, Nowacki Z, et al; Bilastine International Working Group. Efficacy and safety of bilastine $20 \mathrm{mg}$ compared with cetirizine $10 \mathrm{mg}$ and placebo for the symptomatic treatment of seasonal allergic rhinitis: a randomized, double-blind, parallel-group study. Clin Exp Allergy. 2009;39:1338-1347.

58. Bachert C, Kuna P, Sanquer F, et al; Bilastine International Working Group. Comparison of the efficacy and safety of bilastine $20 \mathrm{mg}$ vs desloratadine $5 \mathrm{mg}$ in seasonal allergic rhinitis patients. Allergy. 2009;64:158-165.

59. Bartra J, Mullol J, Montoro J, et al. Effect of bilastine upon the ocular symptoms of allergic rhinoconjunctivitis. J Investig Allergol Clin Immunol. 2011;21(suppl 3):24-33.

60. Sastre J, Mullol J, Valero A; Bilastine Study Group. Efficacy and safety of bilastine $20 \mathrm{mg}$ compared with cetirizine $10 \mathrm{mg}$ and placebo in the treatment of perennial allergic rhinitis. Curr Med Res Opin. 2012;28: $121-130$.

61. Zuberbier T, Oanta A, Bogacka E, et al; Bilastine International Working Group. Comparison of the efficacy and safety of bilastine $20 \mathrm{mg}$ vs levocetirizine $5 \mathrm{mg}$ for the treatment of chronic idiopathic urticaria: a multi-centre, double-blind, randomized, placebo-controlled study. Allergy. 2010;65:516-528.

62. Church MK. Comparative inhibition by bilastine and cetirizine of histamine-induced wheal and flare responses in humans. Inflamm Res. 2011;60:1107-1112.

63. Kulthanan K, Jiamton S, Thumpimukvatana N, Pinkaew S. Chronic idiopathic urticaria: prevalence and clinical course. J Dermatol. 2007;34: 294-301.
64. Krause K, Spohr A, Zuberbier T, Church MK, Maurer M. Up-dosing with bilastine results in improved effectiveness in cold contact urticaria. Allergy. 2013;68:921-928.

65. Garcia-Gea C, Martinez J, Ballester MR, Gich I, Valiente R, Antonijoan RM. Psychomotor and subjective effects of bilastine, hydroxyzine, and cetirizine, in combination with alcohol: a randomized, double-blind, crossover, and positive-controlled and placebo-controlled phase I clinical trials. Hum Psychopharmacol. 2014;29:120-132.

66. Conen S, Theunissen EL, Van Oers AC, Valiente R, Ramaekers JG. Acute and subchronic effects of bilastine $(20$ and $40 \mathrm{mg}$ ) and hydroxyzine (50 $\mathrm{mg}$ ) on actual driving performance in healthy volunteers. J Psychopharmacol. 2011;25:1517-1523.

67. Farre M, Perez-Mana C, Papaseit E, et al. Bilastine vs. hydroxyzine: occupation of brain histamine $\mathrm{H} 1$ - receptors evaluated by positron emission tomography in healthy volunteers. $\mathrm{Br} J$ Clin Pharmacol. 2014;78:970-980.

68. Jauregui I, Ramaekers JG, Yanai K, et al. Bilastine: a new antihistamine with an optimal benefit-to-risk ratio for safety during driving. Expert Opin Drug Saf. 2016;15(1):89-98.

69. Yanai K, Ryu JH, Watanabe T, et al. Histamine H1 receptor occupancy in human brains after single oral doses of histamine $\mathrm{H} 1$ antagonists measured by positron emission tomography. Br J Pharmacol. 1995;116:1649-1655.

70. Yanai K, Okamura N, Tagawa M, Itoh M, Watanabe T. New findings in pharmacological effects induced by antihistamines: from PET studies to knock-out mice. Clin Exp Allergy. 1999;29(suppl 3):29-36.

71. Okamura N, Yanai K, Higuchi M, et al. Functional neuroimaging of cognition impaired by a classical antihistamine, d-chlorpheniramine. Br J Pharmacol. 2000;129:115-123.

72. Tagawa M, Kano M, Okamura N, et al. Neuroimaging of histamine H1-receptor occupancy in human brain by positron emission tomography (PET): a comparative study of ebastine, a second-generation antihistamine and (+)-chlorpheniramine, a classical antihistamine. Br J Clin Pharmacol. 2001;52:501-509.

73. Tashiro M, Sakurada Y, Iwabuchi K, et al. Central effects of fexofenadine and cetirizine: measurement of psychomotor performance, subjective sleepiness, and brain histamine H1-receptor occupancy using 11C-doxepin positron emission tomography. J Clin Pharmacol. 2004;44:890-900.

74. Graff C, Struijk JJ, Kanters JK, Andersen MP, Toft E, Tyl B. Effects of bilastine on T-wave morphology and the QTc interval: a randomized, double-blind, placebo-controlled, thorough QTc study. Clin Drug Investig. 2012;32:339-351.

75. Prepageran N, Wang de Y, Nair G, Maurer M. The status quo and unmet needs in the management of allergic rhinitis and chronic rhinosinusitis: a Malaysian perspective. Asia Pac Allergy. 2014;4:142-148.
Therapeutics and Clinical Risk Management

\section{Publish your work in this journal}

Therapeutics and Clinical Risk Management is an international, peerreviewed journal of clinical therapeutics and risk management, focusing on concise rapid reporting of clinical studies in all therapeutic areas outcomes, safety, and programs for the effective, safe, and sustained use of medicines. This journal is indexed on PubMed Central, CAS,

\section{Dovepress}

EMBase, Scopus and the Elsevier Bibliographic databases. The manuscript management system is completely online and includes a very quick and fair peer-review system, which is all easy to use. Visit http://www.dovepress.com/testimonials.php to read real quotes from published authors. 